\title{
Embryonic Lethal Abnormal Vision-Like RNA-Binding Proteins Regulate Neurite Outgrowth and Tau Expression in PC12 Cells
}

\author{
Gonzalo E. Aranda-Abreu, ${ }^{1}$ Leah Behar, ${ }^{1}$ Sangmi Chung, ${ }^{2}$ Henry Furneaux, ${ }^{2}$ and Irith Ginzburg ${ }^{1}$ \\ ${ }^{1}$ Department of Neurobiology, The Weizmann Institute of Science, 76100 Rehovot, Israel, and ${ }^{2}$ Program in Molecular \\ Pharmacology and Therapeutics, Memorial Sloan-Kettering Cancer Center, New York, New York 10021
}

The embryonic lethal abnormal vision (ELAV)-like proteins are mRNA-binding proteins that regulate mRNA stability. The neuronal members of this family are required for neuronal differentiation. We identified the binding region of purified HuD protein to a target neuronal mRNA encoding for the tau microtubuleassociated protein and demonstrated an in vivo interaction between the ELAV-like protein and its target tau mRNA. We show that treatment of neuronal cells with antisense oligode- oxynucleotides directed against HuD blocks the induction of neurite outgrowth and decreases the levels of tau mRNAs, indicating that the ELAV-like proteins are required for neuronal differentiation.

Key words: RNA-binding proteins; tau mRNA; mRNA stabilization; neurite outgrowth; antisense oligodeoxynucleotides; microtubules
The embryonic lethal abnormal vision (ELAV) gene is required for the development of the Drosophila nervous system (Campos et al., 1985; Jimenez and Campos-Ortega, 1987). In mutant flies the neuroblasts differentiate inappropriately, resulting in a defective nervous system. In normal flies, ELAV is expressed immediately after the neuroblasts withdraw from the cell cycle and continues to be expressed in adult postmitotic neurons (Robinow et al., 1988; Robinow and White, 1991). Continued expression of ELAV in adult neurons is essential for brain function, because temperature-sensitive ELAV mutants are incapacitated at nonpermissive temperatures (Homyk et al., 1985). The ELAV gene product encodes a protein with three characteristic RNA-binding motifs (RRMs) (Robinow et al., 1988). These motifs are found in many RNA-binding proteins that regulate gene expression (Kenan et al., 1991). In view of this, it is thought that ELAV promotes neuronal differentiation by selectively modulating the expression of required genes (Yao et al., 1993; Koushika et al., 1996). However, the mRNA targets regulated by ELAV have yet to be clearly elucidated.

ELAV homologs have been identified in human, mouse, rat, Xenopus, and birds (Abe et al., 1994; King et al., 1994; Good, 1995; Perron et al., 1995; Steller et al., 1996; Ma and Furneaux, 1997; Myer et al., 1997; Okano and Darnell, 1997; Wakamatsu and Weston, 1997). The human members of the family (HuD, Hel-N1, HuC, and HuR) are of particular interest because they were independently discovered as tumor antigens (Szabo et al., 1991; Sakai et al., 1994). A vital clue to the mechanism of action of these proteins in vertebrates was provided by the observation that they bind in vitro to U-rich regulatory elements in the

\footnotetext{
Received Jan. 21, 1999; revised April 28, 1999; accepted June 1, 1999.
}

This work was supported by grants from the Basic Research Foundation (Israel Academy of Sciences and Humanities) and the German-Israeli Foundation (GIF), an AFIRST grant from the France-Israel Ministry of Science (I.G.), and National Science Foundation Grant IBN-9604175 (H.M.F.). I.G. is the incumbent of the Sophie and Richard S. Richard Professorial Chair in Cancer Research. We thank

Dr. Eyal Schejter for his substantial help and comments on the confocal studies.

Correspondence should be addressed to Dr. Irith Ginzburg, Department of Neurobiology, The Weizmann Institute of Science, 76100 Rehovot, Israel. E-mail: bnginzbu@weizmann.weizmann.ac.il

Copyright (C) 1999 Society for Neuroscience $\quad 0270-6474 / 99 / 196907-11 \$ 05.00 / 0$
3'-UTRs (3'-untranslated region) of mRNAs. These U-rich elements were originally described by Shaw and Kamen (1986), who found that they direct the rapid turnover of mRNA. Thus, mRNAs that contain these elements have a very short half-life and are usually present at a very low steady-state level. The mechanism of this rapid turnover is not clear but has been ascribed to a specific endonuclease or an adenylate/uridylate-rich element (ARE)-dependent deadenylase (Chen and Shyu, 1995). The expression of these unstable mRNAs can be increased dramatically by factors that bind to the U-rich elements. Recent evidence has indicated that the ELAV-like proteins are such factors and that they selectively inhibit the decay of mRNAs that contain U-rich elements (Jain et al., 1997; Fan and Steitz, 1998; Levy et al., 1998; Peng et al., 1998).

The transition from neuroblast to postmitotic neuron is accompanied by a regulated increase in the stability of mRNAs that are required for terminal differentiation. The vertebrate ELAV-like proteins have been shown to bind to many such mRNAs in vitro (Gao et al., 1994; King et al., 1994; Chung et al., 1996). This suggests that the vertebrate ELAV-like proteins, like their Drosophila counterparts, play a critical role in neuronal differentiation. It was recently shown that overexpression of $\mathrm{HuD}$ in neural crest cells indeed stimulates their differentiation into mature neurons (Wakamatsu and Weston, 1997). Similarly, transfection with Hel-N1 caused increased translation of neurofilament M mRNA and induced formation of neurites in human teratocarcinoma cells (Antic et al., 1999). It is possible, however, that this does not reflect the normal physiological condition and was the result of an abnormally high $\mathrm{HuD}$ or Hel-N1 in the above cells. We therefore decided to examine whether the endogenous ELAV-like proteins are required for neuronal differentiation. In this investigation we used the PC12 model system, because PC12 cells are known to express at least one ELAV-like family member (Steller et al., 1996). We show that treatment of PC12 cells with antisense oligonucleotide directed against $\mathrm{HuD}$ blocks the induction of differentiation by nerve growth factor (NGF). In the course of these studies we also discovered that tau mRNA is a binding target of the ELAV-like proteins. Tau is a microtubule 
(MT)-associated protein that is essential for neurite development and cell polarity in cultured neuronal cells. Our results show that tau mRNA levels are regulated by $\mathrm{HuD}$. These observations strongly indicate that the vertebrate ELAV-like proteins are required for neuronal differentiation.

\section{MATERIALS AND METHODS}

Cell culture system. PC12 cells were grown in DMEM supplemented with $8 \%$ horse serum and $8 \%$ fetal calf serum at $37^{\circ} \mathrm{C}$ in an $8 \% \mathrm{CO}_{2}$ incubator. For treatment with NGF, 1.2-1.5 $\times 10^{6}$ cells were plated on $90 \mathrm{~mm}$ collagen-coated dishes and grown in DMEM supplemented with $1 \%$ horse serum, $2 \mathrm{~mm}$ glutamine, $50 \mathrm{U} / \mathrm{ml}$ penicillin, $50 \mu \mathrm{g} / \mathrm{ml}$ streptomycin, and $50 \mathrm{ng} / \mathrm{ml} 7 \mathrm{~S}$ NGF (Alamone, Jerusalem, Israel). NGF was added every $2 \mathrm{~d}$.

Antisense treatment. The experiments were performed with $\mathrm{r}-\mathrm{HuD}$ sense and antisense oligodeoxynucleotide (oligo) 5'-TGGATGTCGG TCCATTTGAC-3' (15-34) (Steller et al., 1996) or with the unrelated AC6 antisense oligo (NRO) 5'-AAGCAAACAGCCTTACTC-3' (Premont et al., 1992). There was no significant homology between the r-HuD antisense oligonucleotide and any other sequence in the database.

PC12 cells were plated on collagen-coated microtiter plates at a density of $1 \times 10^{5}$ cells per well and grown in DMEM supplemented with 10 $\mu \mathrm{g} / \mathrm{ml}$ insulin, $10^{-8} \mathrm{M}$ hydrocortisone, $5 \mu \mathrm{g} / \mathrm{ml}$ transferrin, $10 \mu \mathrm{g} / \mathrm{ml}$ somatostatin, and $10 \mu \mathrm{g} / \mathrm{ml}$ glycyl-L-hystidyl-lysine, $50 \mathrm{U} / \mathrm{ml}$ penicillin, and $50 \mu \mathrm{g} / \mathrm{ml}$ streptomycin (Sigma, St. Louis, MO). They were then treated with $50 \mu \mathrm{M}$ unmodified antisense oligonucleotide in the presence of $50 \mathrm{ng} / \mathrm{ml} \mathrm{NGF}$ for the specified time periods. The morphological appearance of the treated PC12 cells was observed by light microscopy. At the end of the experiment, RNA was isolated and amplified as described below.

Preparation of cell extracts and microtubules. S100 extracts were prepared in TGKED buffer [50 mM Tris, $\mathrm{pH} 7.5,25 \%$ glycerol, $50 \mathrm{~mm} \mathrm{KCl}$, $0.1 \mathrm{~mm}$ EDTA, $0.5 \mathrm{~mm}$ DTT, $1 \mathrm{~mm}$ phenylmethanyl-sulfonyl fluoride (PMSF)]. Cells were homogenized in 2 vol of TGKED buffer, cleared of cell debris by centrifugation in a microfuge at $12,000 \times g$ for $10 \mathrm{~min}$ at $4^{\circ} \mathrm{C}$, and then centrifuged in a Beckman airfuge for $15 \mathrm{~min}$ at $100,000 \times$ $g$ in the cold. Extracts were stored as aliquots at $-80^{\circ} \mathrm{C}$. Protein concentrations were determined by the Bradford method and ranged from 5 to $10 \mu \mathrm{g} / \mu \mathrm{l}$.

MTs were prepared from PC12 cells after two cycles of in vitro assembly (Shelanski et al., 1973). The final MT pellets were resuspended in TGKED buffer and stored as aliquots at $-80^{\circ} \mathrm{C}$ until use.

Preparation of RNA transcripts. Plasmids encoding the F, G, H, I, and J fragments (Behar et al., 1995) were linearized with HindIII, HindIII, SacI, StyI, and SacI, respectively. The plasmid Gdel was derived by PCR deletion of the 21 nucleotides AU-rich region from fragment $G$ and linearized with BamHI. Template DNAs were transcribed with the appropriate RNA polymerase in the presence of $\left[{ }^{32} \mathrm{P}\right]-\mathrm{UTP}$ (Amersham, Arlington Heights, IL). All transcripts were gel-purified as described previously (Behar et al., 1995).

$R N A$ complex assay. Reaction mixtures $(20 \mu \mathrm{l})$ contained $50 \mathrm{~mm}$ Tris, $\mathrm{pH} 7.0,150 \mathrm{~mm} \mathrm{NaCl}, 0.25 \mathrm{mg} / \mathrm{ml}$ tRNA (Boehringer Mannheim, Mannheim, Germany), $0.25 \mathrm{mg} / \mathrm{ml}$ bovine serum albumin (BSA), $30 \mathrm{fmol}$ labeled RNA, and purified HuD protein, as indicated. After incubation at $37^{\circ} \mathrm{C}$ for $10 \mathrm{~min}, 5 \mu \mathrm{l}$ of a dye mixture $(50 \%$ glycerol, $0.1 \%$ bromophenol blue, $0.1 \%$ xylene cyanol) was added, and $5 \mu \mathrm{l}$ of the reaction mixture was then immediately loaded on a $1 \%$ agarose gel in TAE buffer (40 mm Tris-acetate, $1 \mathrm{~mm}$ EDTA). The gel was then electrophoresed at $40 \mathrm{~V}$ for $2.5 \mathrm{hr}$, dried on DE-81 paper (Whatman) with a backing of gel-drying paper (Hudson City Paper), and exposed to XAR5 film (Kodak, Rochester, NY) for $6 \mathrm{hr}$ at $-70^{\circ} \mathrm{C}$.

Nitrocellulose filter binding assay. Reaction mixtures $(20 \mu \mathrm{l})$ contained $50 \mathrm{~mm}$ Tris, pH 7.0, $150 \mathrm{~mm} \mathrm{NaCl}, 0.25 \mathrm{mg} / \mathrm{ml} \mathrm{BSA}, 0.25 \mathrm{mg} / \mathrm{ml}$ tRNA (Boehringer Mannheim), $30 \mathrm{fmol}$ radiolabeled mRNA, and purified $\mathrm{HuD}$ as indicated. After incubation for $10 \mathrm{~min}$ at $37^{\circ} \mathrm{C}$, the mixtures were diluted 1:6 with buffer F (20 mM Tris, pH 7.0, $150 \mathrm{~mm} \mathrm{NaCl}, 0.25 \mathrm{mg} / \mathrm{ml}$ tRNA) and filtered through nitrocellulose (BA85, Schleicher \& Schuell, Keene, NH). The filter was washed twice with buffer F. Bound radioactivity was determined by Cerenkov counting.

RNase T1 selection assay. Reaction mixtures $(20 \mu \mathrm{l}$; see preceding section for contents) were incubated for $10 \mathrm{~min}$ at $37^{\circ} \mathrm{C}$. RNase T1 (5 U) (Calbiochem, La Jolla, CA) was added, and the reaction was allowed to continue for an additional $10 \mathrm{~min}$. The mixtures were diluted 1:6 with buffer (20 mm Tris, $\mathrm{pH} 7.0,150 \mathrm{~mm} \mathrm{NaCl})$ and filtered through nitrocel- lulose (BA 85, Schleicher \& Schuell). The nitrocellulose filter was washed twice with buffer, and the bound RNA was eluted by phenol-chloroform extraction. The resultant RNA was mixed with formamide buffer, denatured at $65^{\circ} \mathrm{C}$ for $3 \mathrm{~min}$, and analyzed by electrophoresis ( $12 \%$ polyacrylamide/urea gel). The gel was fixed with acetic acid/methanol/water 1:1:8, dried on DE-81 paper with a backing of gel-drying paper, and exposed to the XAR5 film at $-70^{\circ} \mathrm{C}$ overnight.

Antibodies. High-titer polyclonal human antisera (1:1000), which specifically recognize ELAV-like proteins (Szabo et al., 1991), were purified and further analyzed by Athena Diagnostic (Boston, MA). These antibodies were initially used to screen a cDNA expression library and were found to encode for one gene product, HuD (Szabo et al., 1991) (GenBank accession no. M62843). Anti-HuD monoclonal antibodies (4 $\mu \mathrm{g} /$ ml) (Marusich et al., 1994) were prepared by immunization using peptide antigen. The tau-1 monoclonal antibodies $(2.5 \mu \mathrm{g} / \mathrm{ml})$ were obtained from (Binder et al., 1985) actin monoclonal antibodies (1:2000; Sigma), and monoclonal anti-tubulin (1:500; BioMakor). Secondary antibodies (goat anti-human and goat anti-mouse) were obtained from Jackson ImmunoResearch (West Grove, PA).

UV cross-linking assay and immunoprecipitation. $\alpha-\left[{ }^{32} \mathrm{P}\right] \mathrm{UTP}-\mathrm{labeled}$ RNA transcripts at the specified amounts $\left(8 \mathrm{fmol}, 2 \times 10^{5} \mathrm{cpm}\right)$ were incubated with $10 \mu \mathrm{g}$ of PC12 cells (S100 extracts), $10 \mu \mathrm{g}$ of MT preparation, or $100 \mathrm{ng}$ of glutathione $S$-transferase (GST)-HuD-purified fusion protein in a final volume of $0.02 \mathrm{ml}$. After $30 \mathrm{~min}$ at room temperature, heparin (Sigma) was added at a final concentration of 5 $\mathrm{mg} / \mathrm{ml}$, and the samples were irradiated at $0.5 \mathrm{~J} / \mathrm{cm}^{2}$ with a $254 \mathrm{~nm} \mathrm{UV}$ light source (Spectrolinker XL-1500 UV cross-linker). After incubation with $1 \mathrm{mg} / \mathrm{ml} \mathrm{RNase}$ A (Sigma) for $15 \mathrm{~min}$ at $50^{\circ} \mathrm{C}$, samples were either directly analyzed on $12 \%$ SDS-PAGE or immunoprecipitated with polyclonal human antisera for $1 \mathrm{hr}$ at $4^{\circ} \mathrm{C}$. This was followed by incubation with protein A-Sepharose (Pharmacia, Piscataway, NJ) for $1 \mathrm{hr}$ at $4^{\circ} \mathrm{C}$. Complexes were collected, denatured at $65^{\circ} \mathrm{C}$, and resolved by $12 \%$ SDS-PAGE.

Purification of GST-HuD proteins. An overnight culture of Escherichia coli BL 21, transformed with pGST-HuD (Chung et al., 1996), was diluted 1:50 in LB medium. At an $\mathrm{OD}_{600}$ of 0.4 , the culture was induced with isopropyl $\beta$-D thiogalactopyranoside $(0.1 \mathrm{~mm})$. After $4 \mathrm{hr}$ of further growth, the cells were spun down and resuspended in $10 \mathrm{ml}$ of buffer $\mathrm{A}$ (50 mm Tris, pH 8.0, $200 \mathrm{~mm} \mathrm{NaCl}, 1 \mathrm{~mm}$ EDTA). The cells were lysed by the addition of lysozyme $(0.2 \mathrm{mg} / \mathrm{ml})$ and Triton X-100 $(1 \%)$. The lysate was centrifuged at $12,000 \times g$ for $30 \mathrm{~min}$, and the resulting supernatant was loaded onto a glutathione-agarose affinity column (13 $\mathrm{mg}$ of protein per milliliter of resin). The column was washed with buffer B (50 mm Tris, pH 8.0, $200 \mathrm{~mm} \mathrm{NaCl,} 1$ mm EDTA, 1\% Triton X-100), and GST-HuD was eluted with $50 \mathrm{~mm}$ Tris, $\mathrm{pH} 8.0$, containing $5 \mathrm{~mm}$ glutathione. Active protein was determined by RNA-complex formation. They were then pooled and stored at $-70^{\circ} \mathrm{C}$, as described previously (Chung et al., 1996).

Immunoblot analysis of $\mathrm{PC} 12$ protein extracts. For immunoblot analysis of PC12 proteins, cells were extracted in 1 vol of lysis buffer $(50 \mathrm{~mm}$ Tris, $\mathrm{pH} 8.5,1 \%$ Triton X-100, 5 mм EDTA, 0.15 м NaCl, $50 \mu \mathrm{g} / \mathrm{ml}$ PMSF). Cell extracts were cleared of cell debris by centrifugation for $10 \mathrm{~min}$ at $14,000 \times g$ at $4^{\circ} \mathrm{C}$.

Protein samples $(25 \mu \mathrm{g})$ were resolved by SDS-gel electrophoresis, transferred to nitrocellulose filters, and reacted with specified antibodies at $4^{\circ} \mathrm{C}$ for $16 \mathrm{hr}$. They were then visualized by reaction with peroxidaseconjugated goat anti-human or goat anti-mouse secondary antibodies at room temperature for $1 \mathrm{hr}$ and developed using the ECL chemiluminescence procedure.

Cell fractionation. PC12 cells were extracted under conditions that preserve preexisting MTs in the cells and allow for separation between MTs assembled in vivo and unassembled tubulin (Black and Kurdyla, 1983). Cultures were rinsed twice with $\mathrm{Ca}^{2+}$-free and $\mathrm{Mg}^{2+}$-free PBS, and the cells were collected and homogenized in $100 \mathrm{mM}$ PIPES buffer, pH 6.9, containing $1 \mathrm{~mm} \mathrm{MgSO}_{4}, 0.5 \%$ Triton X-100, and protease inhibitors [ $1 \mathrm{~mm}$ PMSF, $10 \mathrm{mg} / \mathrm{ml}$ aprotinin, $10 \mathrm{mg} / \mathrm{ml}$ leupeptin, and 10 $\mathrm{mg} / \mathrm{ml}$ pepstatin (Sigma)] in the presence of MT-stabilizing reagents (4 M glycerol, 5\% v/v dimethylsulfoxide, $5 \mu \mathrm{M}$ Taxol, and $1 \mathrm{~mm}$ EGTA). After centrifugation of the homogenate at $12,000 \times g$ in an Eppendorf centrifuge for $5 \mathrm{~min}$, the supernatant was removed and centrifuged at $32,000 \times g$ in a Beckman airfuge for $30 \mathrm{~min}$ at room temperature. Under these conditions the in vivo cellular composition is preserved: unpolymerized proteins remain in the supernatant, but the in vivo MT fraction, being insoluble, is found in the pellet (Black and Kurdyla, 1983; Litman et al., 1994). 

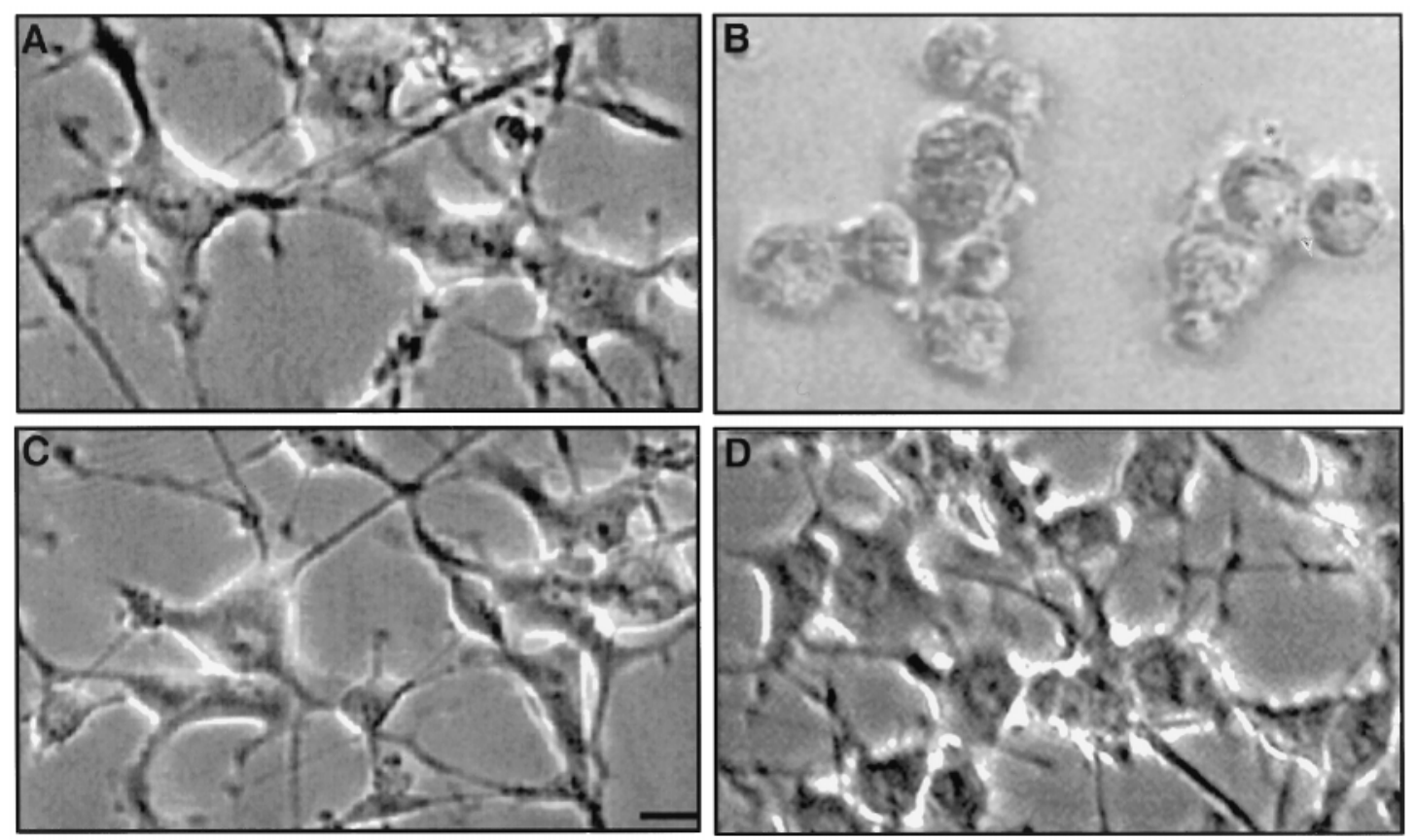

Figure 1. Effect of r-HuD antisense treatment on neurite outgrowth in PC12 cells. $A$, Control PC12 cells treated with NGF for $4 \mathrm{~d}$. $B$, PC12 cells treated with NGF and r-HuD antisense oligonucleotides for 4 d. $C$, PC12 cells treated with NGF and unrelated AC6 antisense oligonucleotides. $D$, PC12 cells treated with NGF and sense r-HuD oligonucleotides for $4 \mathrm{~d}$. Scale bar, $20 \mu \mathrm{m}$.

Immunoprecipitation analysis of PC12 cellular extracts. PC12 cells were lysed in 1 vol of lysis buffer $(50 \mathrm{~mm}$ Tris, $\mathrm{pH} 7.5,25 \%$ glycerol, $50 \mathrm{~mm}$ $\mathrm{KCl}, 0.1 \mathrm{~mm}$ EDTA, $0.5 \mathrm{~mm}$ DTT, $1 \mathrm{~mm}$ PMSF, 0.5\% NP-40, $40 \mathrm{U} / \mu \mathrm{l}$ RNasin, 10 mm vanadyl complex) and cleared of cell debris by centrifugation at $14,000 \times g$ at $4^{\circ} \mathrm{C}$. Anti-Hu sera $(1: 1000)$ was added, and the mixture was incubated for $1 \mathrm{hr}$ at $4^{\circ} \mathrm{C}$ and then for another hour at $4^{\circ} \mathrm{C}$ with protein A-Sepharose (Pharmacia; 10\% final concentration). The immunocomplex was precipitated by centrifugation, washed, and processed for RNA isolation as described below.

Similar procedures were performed when MT fractions were used for immunoprecipitation experiments.

$R N A$ isolation and RT-PCR analysis. RNA was isolated from total cell extracts or from the immunoprecipitated complex using RNAzol reagent (Biotecx Laboratories, Houston, TX). The extracted RNA was reverse-transcribed with random hexamers using the standard procedure in a $20 \mu \mathrm{l}$ reaction mixture. Aliquots of $5 \mu \mathrm{l}$, from the RT mixture, were used for amplification, using the following primers: for $\mathrm{r}-\mathrm{HuD}, 5^{\prime}$-CCAA CAAAGCCCACAAGTCC-3' (1226-1245) and 5'-AATCCTTTCCT GGTACACCTCA-3' (1410-1431) (Steller et al., 1996); for tau, 5'-GG TGAGGGATGGGGGTGGTA-3' (2179-2198) and 5'-GTGACTGG CTCTCGTGGCA-3' (2278-2297) (Sadot et al., 1994); for GADPH, 5'-GCCATCAACGACCCCTTCAT-3' (118-137) and 5'-TTCACACC CATCACAAACAT-3' (412-431) (Tso et al., 1985); for actin, 5'GCACCACACTTTCTACAATGA-3' (1585-1606) and 5'-GAACCG CTCATTGCCGATAGT-3' (2537-2558) (Nudel et al., 1983) (this published sequence includes an intron between 1692 and 2155); for AC6, 5'-CTTCCAGATGAAGATCGGG-3' (3289-3308) and 5' AAGCAAACAGCCTTACTC 3' (3778-3796) (Premont et al., 1992); for p75NGFR, 5'-GTCGTGGGCCTTGTGGCC-3' (903-921) and 5'-CTGTGAGTT CACACTGGGG-3' (1381-1400) (Radeke et al., 1987); for TrkA, 5'CGTTGATGCTGGCTTGTGC-3' (135-153) and 5'-GGAGAGATT CAGGTGACTGA-3' (411-430) (Meakin et al., 1992).

The amplification program consisted of one cycle at $94^{\circ} \mathrm{C}$ for $5 \mathrm{~min}$, followed by 30 cycles at $94^{\circ} \mathrm{C}$ for $1 \mathrm{~min}$, at $55^{\circ} \mathrm{C}$ for $1 \mathrm{~min}$, and at $72^{\circ} \mathrm{C}$ for 2 min.

Confocal microscopy analysis of PC12 cells. PC12 cells were grown on coverslips coated with collagen type 1 . The cells were fixed with $4 \%$ paraformaldehyde in $4 \%$ sucrose for $30 \mathrm{~min}$ at room temperature. They were then permeabilized by incubation for $3 \mathrm{~min}$ in $0.5 \%$ Triton X-100, washed three times with PBS, and blocked with $1 \%$ BSA. The cells were incubated with the primary antibodies monoclonal anti-tubulin (1:500)
(Bio-Makor) or anti-Hu sera (1:250), or a mixture of the two, for $24 \mathrm{hr}$ at $4^{\circ} \mathrm{C}$. They were then washed three times, each for $15 \mathrm{~min}$, with PBS and incubated for $2 \mathrm{hr}$ at room temperature with the secondary antibodies goat anti-mouse FITC (1:100) (Bio-Makor) and goat anti-human $\mathrm{C}_{\mathrm{y}} 3$ (1:100) (Jackson ImmunoResearch) for anti-tubulin and anti-ELAV-like antibodies, respectively. The coverslips were mounted with Mowiol and visualized with the MRC-1024 confocal laser scanning imaging system (Bio-Rad, Richmond, CA) at $40 \times$ objective, using green and red filters for tubulin and human antibodies, respectively. The images were analyzed using software for the MRC-1024 confocal imaging system.

\section{RESULTS}

\section{Effect of treatment with r-HuD oligo antisense on the morphology of PC12 cells}

To determine whether inhibition of ELAV-like gene expression affects neurite outgrowth in PC12 cells induced by NGF, we focused on one member of the ELAV family of proteins, r-HuD, which is expressed in and has been cloned from PC12 cells (Steller et al., 1996). We applied r-HuD-specific antisense oligonucleotides $(50 \mu \mathrm{M})$ to NGF-treated PC12 cells for up to $4 \mathrm{~d}$ and followed the effect on neurite outgrowth.

In untreated control cells, NGF treatment resulted in extension of neurites (Fig. 1A). In cells subjected to antisense treatment, neurite retraction was clearly evident from day 2 after the start of treatment, and after day 4 the cells exhibited the morphology of noninduced cells (Fig. $1 B$ ). Similar findings were recently obtained by Dobashi et al. (1998). Cells treated with sense oligo or with an unrelated oligo antisense (NRO) directed against adenyl cyclase type VI were not affected, i.e., their morphology was similar to that of untreated control cells (Fig. $1 C, D$ ). At this stage, replacement of the medium by fresh medium without the antisense oligos from the treated cells led to their full recovery. Similar results were reported when PC12 or primary cerebellar cells were treated with these concentrations of tau antisense (Caceres and Kosik, 1990; Hanemaaijer and Ginzburg, 1991). 
A
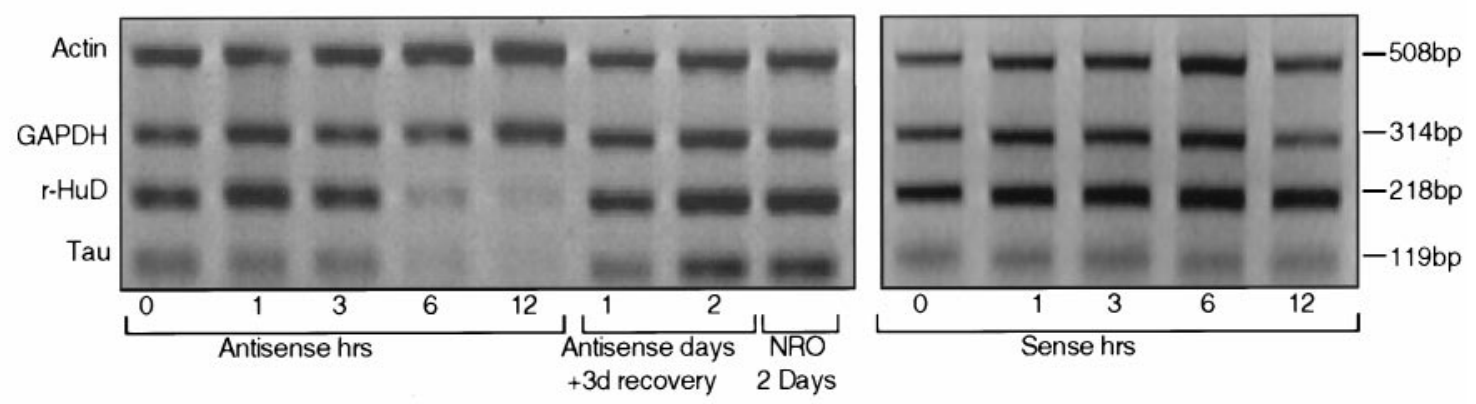

B

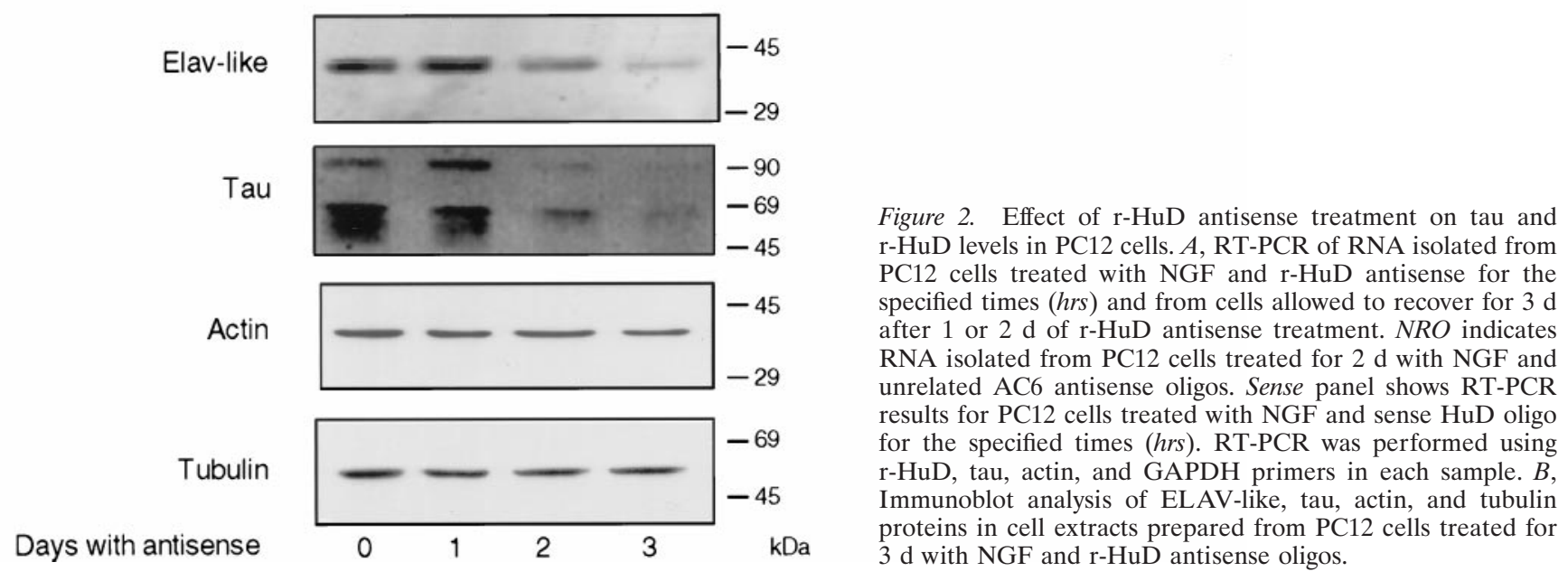

\section{Treatment with antisense to r-HuD decreases r-HuD and tau mRNAs and proteins}

Because tau mRNA and proteins are involved in neurite outgrowth, we were interested in examining their response to treatment with antisense to r-HuD. PC12 cells were induced with NGF in the presence of r-HuD antisense oligos for the indicated periods. Total RNA was extracted from equal numbers of control and antisense-treated cells, and the amounts of r-HuD and tau mRNAs were determined by RT-PCR, using r-HuD- and tauspecific primers. One of the two primers used to amplify $\mathrm{r}-\mathrm{HuD}$ was a downstream $3^{\prime}$ primer complementary to a sequence located in the $3^{\prime}$-UTR of $\mathrm{r}-\mathrm{HuD}$, a region that is divergent among the ELAV family members (Szabo et al., 1991; King et al., 1994; Steller et al., 1996) (GenBank accession no. L26405). Use of this primer yields an expected PCR fragment of 218 base pairs (bp). No PCR product was obtained when the RT step was omitted, indicating the absence of DNA contamination in the isolated RNA (data not shown). A decrease in the amounts of r-HuD and tau mRNAs was observed after the $\mathrm{r}-\mathrm{HuD}$ antisense treatment (Fig. 2A). The decrease was already apparent after $6 \mathrm{hr}$ of treatment but was more pronounced for tau mRNA than for $\mathrm{r}-\mathrm{HuD}$ mRNA. After treatment for $12 \mathrm{hr}$, both the r-HuD and the tau signals had almost disappeared.

When the medium was replaced by fresh medium without the $\mathrm{r}-\mathrm{HuD}$ antisense oligo, both $\mathrm{r}-\mathrm{HuD}$ and tau mRNAs increased to the amounts observed in untreated control cells. As in the previous morphological experiment (Fig. 1), treatment of PC12 cells with $\mathrm{r}-\mathrm{HuD}$ sense oligo or NRO-AC6 had no effect on the levels of the tested RNAs. Control mRNAs, monitored by GAPDH and actin primers, were not affected by the treatment.
Immunoblot analysis of protein extracts prepared from $\mathrm{PC12}$ cells treated with $\mathrm{r}-\mathrm{HuD}$ antisense showed that both ELAV-like and tau proteins were markedly decreased after $2 \mathrm{~d}$ (Fig. $2 B$ ). In addition, the amounts of actin and tubulin proteins were not affected by the antisense treatment, in line with the above results showing no reduction in actin mRNA. These results are in agreement with the morphological changes (neurite retraction) observed from $2 \mathrm{~d}$ after antisense administration (Fig. 1). Thus, the decrease in r-HuD RNA and ELAV-like proteins is correlated with the decrease in tau mRNA and proteins.

\section{ELAV-like protein binds to tau mRNA in vivo}

To determine whether the ELAV-like proteins bind to tau RNA in vivo, we prepared total cell extracts from NGF-treated PC12 cells and subjected them to immunoprecipitation with anti-HuD serum (see Materials and Methods). RNA was isolated from the immunoprecipitated pellet $(\mathrm{P})$ and supernatant $(\mathrm{S})$ fractions and analyzed by RT-PCR, using tau or control primers specific for AC6, p75NGFR, and TrkA (Fig. 3). AC6 encodes for adenyl cyclase type VI; p75NGFR and TrkA encode for low- and highaffinity receptors for NGF, respectively, all of which are expressed in PC12 cells (Radeke et al., 1987; Meakin et al., 1992; Premont et al. 1992), and their amplification products are observed when total PC12 RNA is used (Fig. 3, lanes 8-9).

The results show that tau mRNA was present in the immunoprecipitated complex formed with anti-HuD serum, whereas no AC6 products were observed (Fig. 3, lane 1). Assay of the supernatant fraction using tau and AC6 primers showed no tau-specific product but revealed positive reaction with AC6 primers (Fig. 3, lane 3). No tau or AC6 products were obtained in the immuno- 


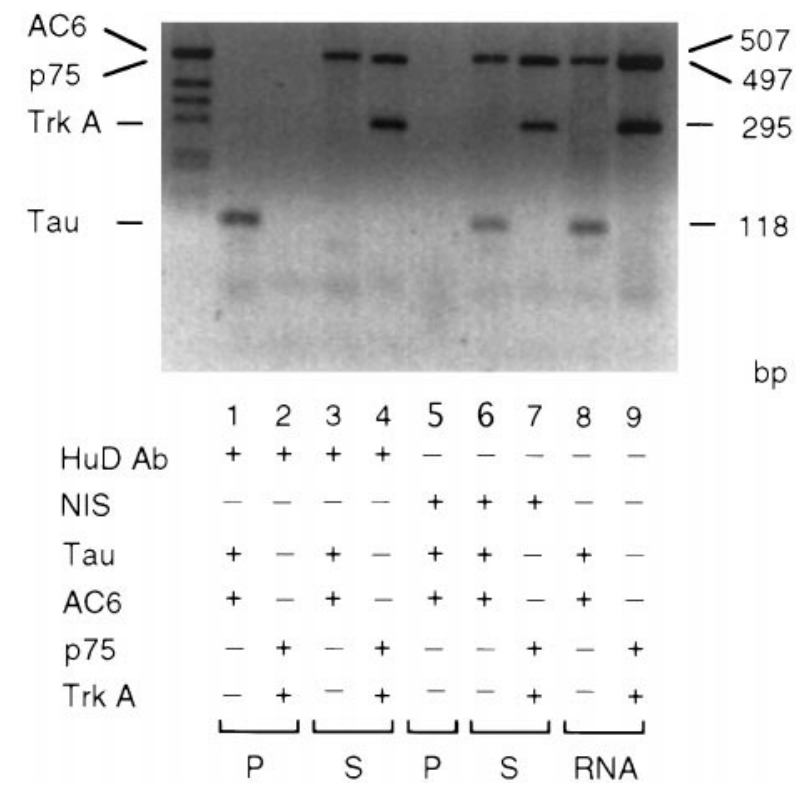

Figure 3. Binding of tau mRNA to ELAV-like proteins in vivo: immunoprecipitation of tau mRNA-ELAV-like complex, followed by isolation and RT-PCR analysis of RNA. PC12 cell extracts were immunoprecipitated with anti-Hu serum. The RNA isolated from the immunoprecipitated complex $(P)$ and the remaining supernatant $(S)$ were assayed by RT-PCR with tau and AC6 primers (lanes 1, 3) and with p75NGFR and TrkA primers (lanes 2, 4). Lanes 5-7, Cell extracts immunoprecipitated with nonimmune serum (NIS) were assayed with tau and AC6-specific primers (lane 5, 6) and with p75NGFR and TrkA primers (lane 7). RT-PCR products using total RNA isolated from PC12 cells were amplified with tau and AC6-specific primers (lane 8) and with p75NGFR and TrkA primers (lane 9). The sizes of RT-PCR products obtained with AC6, p75NGFR, TrkA, and tau primers are 507, 497, 295 and 118 bp, respectively.

precipitated complex when nonimmune serum (NIS) was used (Fig. 3, lane 5). Using p75NGFR and TrkA primers, no products were observed in the immunoprecipitated complex formed with anti -HuD serum (Fig. 3, lane 2). Products were observed in the supernatant fractions remaining after immunoprecipitation with either HuD antibodies (Fig. 3, lane 4) or NIS (Fig. 3, lane 7). These results indicate that $\mathrm{HuD}$ antibodies precipitated the tau mRNA in the immunoprecipitated complex, whereas the other tested messages remained in the supernatant fraction.

\section{The ELAV-like protein-tau mRNA complex is associated with microtubules in vivo}

As a follow-up to the above experiment with total PC12 cellular fractions, and in light of previous evidence that tau mRNA is bound to MTs (Litman et al., 1994), it was of interest to determine whether the complex formed between the ELAV-like proteins and the tau mRNA is associated with the MT fraction in the cell. The polymerized MT fraction preexisting in the cells was isolated as described in Materials and Methods and then subjected to immunoprecipitation with anti-ELAV-like serum. RNA was isolated from the immunoprecipitated complex and from the initial supernatant (Sup) fraction and analyzed by RT-PCR. The results showed that tau mRNA is associated with the immunoprecipitated complex isolated from the MT fraction and is not detected in the unpolymerized supernatant fraction (Fig. 4, lanes $1,3)$. When the same fractions were assayed with AC6 primers, amplification products were detected only in the supernatant (Fig.

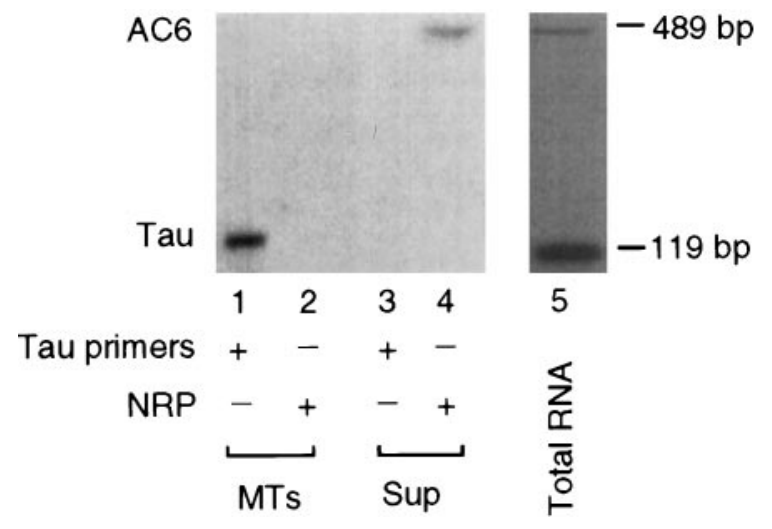

Figure 4. Association of tau mRNA-ELAV-like protein complex with MTs in vivo. Preexisting polymerized microtubules (MTs) and unpolymerized supernatant (Sup) fractions were prepared from PC12 cells. The MT fraction was immunoprecipitated by anti-Hu serum. RNA was isolated from the MT-immunoprecipitated complex and the initial supernatant, and analyzed by RT-PCR using tau-specific (lanes 1, 3) and AC6-specific NRP (lanes 2, 4) primers. Lane 5 is similar to lane 8 in Figure 3.

4, lane 4). This association among tau mRNA, MTs, and ELAVlike proteins is in agreement with our previous results showing that proteins of 38 and $43 \mathrm{kDa}$ that bound to the tau $3^{\prime}$-UTR were enriched in the MT fraction (Behar et al., 1995).

The colocalization of ELAV-like proteins with the MTs in PC12 cells was analyzed by confocal microscopy. PC12 cells were treated for $3 \mathrm{~d}$ with NGF, by which time a substantial neurite outgrowth was observed (Fig. 5). Staining of the cells with tubulin antibodies revealed a typical array of MTs (Fig. $5 A, B$ ), similar to that observed on staining with the anti-ELAV-like antibodies. The staining was observed in the cell bodies and extended into the neurites and growth cones. The overlap images between the fluorescent signals of tubulin and ELAV-like signals seen in Figure 5, $A$ and $D$, and between $B$ and $E$, are shown in $G$ and $H$, respectively. The computerized image analysis of the pictures reveals overlapping of the two antibodies, suggesting that the ELAV-like proteins in PC12 cells associate with the MTs.

Control experiments showed no penetration of $\mathrm{Cy} 3$ or fluorescein signals into the opposite windows (Fig. 5, $C$ and $F$, respectively), and no staining was observed when the primary antibodies were omitted (data not shown).

\section{The 38-43 kDa tau mRNA-binding proteins correspond to protein of the ELAV-like family}

A schematic outline depicting tau mRNA and the fragments of the $3^{\prime}$-UTR of tau mRNA used in this study (segments F, G, H, $\mathrm{I}, \mathrm{J}$ ) is presented in Figure 6. In an earlier study (Behar et al., 1995), we showed that RNAs transcribed from fragments $G, H$, and I cross-link to the 43 and $38 \mathrm{kDa}$ proteins present in extracts prepared from rat brain and PC12 cells. No cross-linking was observed with other RNAs transcribed from tau coding or untranslated regions. In an attempt to determine whether the 38 and $43 \mathrm{kDa}$ proteins are related to the ELAV-like protein family, we subjected the labeled cross-linked material to immunoprecipitation with serum specific for the ELAV-like protein family (Szabo et al., 1991). As shown in Figure 7, this serum precipitated labeled $43 \mathrm{kDa}$ protein from UV cross-linked material formed between labeled RNA transcribed from fragment I and total proteins 

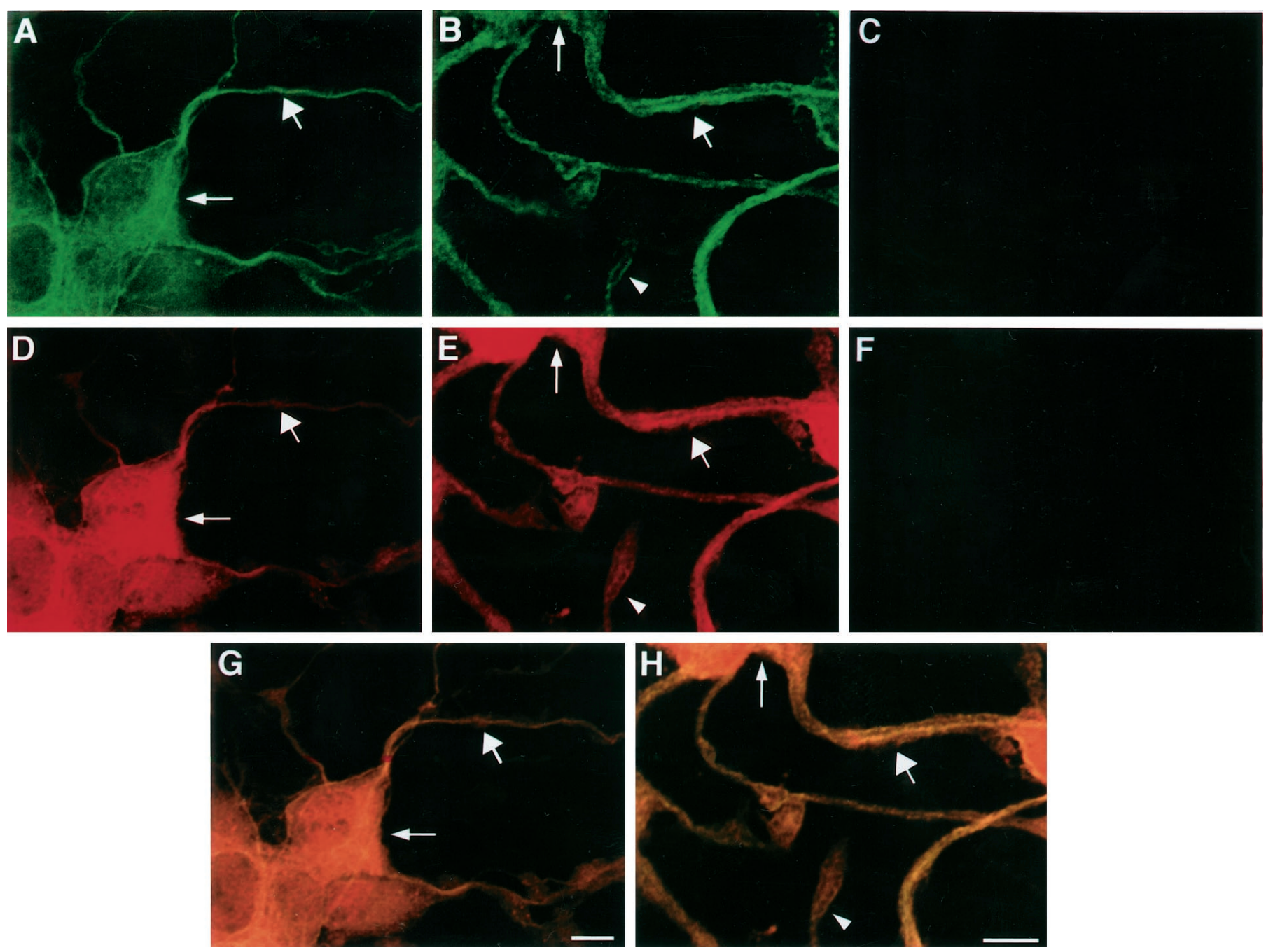

Figure 5. Confocal microscopy analysis of PC12 cells stained with tubulin and anti-ELAV-like antibodies. $A, B$, Confocal image of PC12 cells stained with tubulin antibodies. $D, E$, Confocal image of PC12 cells stained with anti-Hu serum. $C, F$, Control experiments showing no penetration of Cy3 or fluorescein signals into the opposite windows. Thin arrow, wide arrow, and arrowhead indicate cell body, neurite, and growth cone, respectively. Magnification: $5 \times$ for $A, D, G ; 6 \times$ for $B, E, H$. Scale bar, $5 \mu \mathrm{m}$.

extract (lane 1) or MT-enriched fraction (lane 2), both prepared from PC12 cells. The $43 \mathrm{kDa}$ species was not precipitated by nonimmune serum (lane 4 ). In view of these results, we conclude that the previously identified $43 \mathrm{kDa}$ tau mRNA-binding protein belongs to the ELAV-like protein family. This conclusion is based on the following argument. There are three neuronal members of the ELAV-like protein family, namely $\mathrm{HuD}, \mathrm{HuC}$, and HelN1 (Szabo et al., 1991; King et al., 1994; Sakai et al., 1994), which are indistinguishable when immunoprecipitated with anti-Hu sera or with mAb 16A11 (Szabo et al., 1991; Marusich et al., 1994). The lower cross-linked protein band (observed in the total PC12 extract) (Fig. 7, lane 5) was not precipitated by the antiserum. This may indicate that it is a fragment of the ELAV-like protein, which does not contain the antibody epitope. Alternatively, it may represent another RNA-binding protein, which does not belong to the ELAV-like protein family. The sequence of the recently cloned rat homolog r-HuD, expressed in PC12 cells, shares 99.5 and $95 \%$ identity at the protein and DNA levels, respectively, to human HuD (Steller et al., 1996).

\section{Characterization of HuD-tau mRNA complex formation}

Although it is clear that the ELAV-like proteins are bound to tau mRNA, it is possible that efficient binding requires the participation of co-factors in the extract. We therefore examined whether purified $\mathrm{HuD}$ can bind to a specific fragment of tau mRNA. Purified recombinant $\mathrm{HuD}$ was incubated with labeled RNA (Fig. 6, fragments $F$ and $H$ ), and complex formation was assayed by gel retardation analysis, as described previously (Chung et al., 1996). $\mathrm{HuD}$ bound with high affinity to tau-H RNA but not to tau-F RNA (Fig. 8). No complexes were detectable in the absence of $\mathrm{HuD}$ or in the presence of $200 \mathrm{~nm}$ GST fusion carrier protein. Thus, the presence of purified HuD is sufficient to reconstitute the binding. The interaction between $\mathrm{HuD}$ and tau-H RNA was examined further by means of a quantitative RNA binding assay. We used the same method as that originally used for the R17 coat protein (Carey et al., 1983). A low concentration of labeled RNA was incubated with increasing concentrations of $\mathrm{HuD}$ protein as indicated. The reaction mixture was filtered through nitrocellulose, and the bound radioactivity was determined. As shown in 

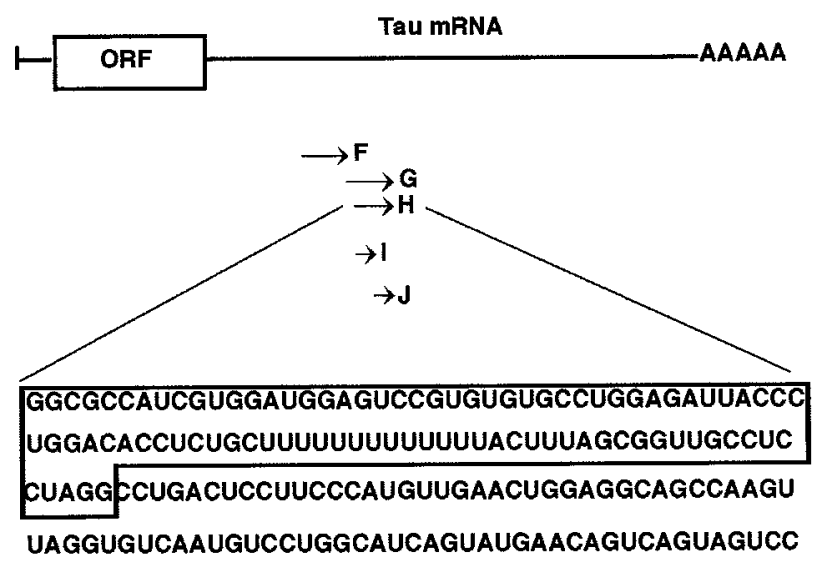

CAGGGCAGGGCCACACUUCUCCCAUCUUCUGCUUCCACCCCAG

CUUGUGAUUGCUAGCCUCCCAGAGCU

Figure 6. Structure of tau mRNA. The fragments $(F, G, H, I$, and $J)$ used in this study correspond to nucleotides $1778-2175$ (397 bp), 2175-2760 (624 bp), 2519-2760 (241 bp), 2519-2610 (91 bp), and 2610-2760 (150 $\mathrm{bp}$ ), respectively (Sadot et al., 1994). The 241-nucleotide sequence of fragment $\mathrm{H}$ is presented, and the I fragment containing the U-rich segment is boxed. The U-rich 21 nucleotides are deleted from fragment $\mathrm{G}$ (Gdel).

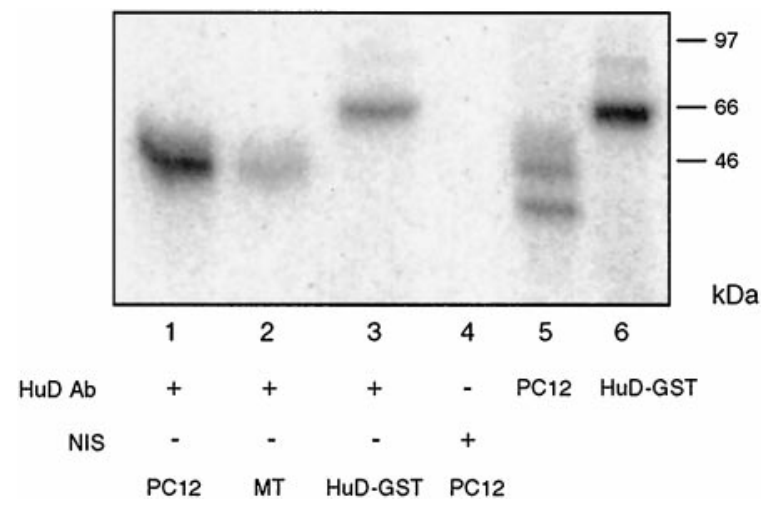

Figure 7. Immunoprecipitation of UV cross-linked complexes by anti-Hu ELAV-like antibodies: SDS gel analysis of immunoprecipitated complexes formed between PC12 cell extracts (lane 1), assembled MT preparations isolated from PC12 cells (lane 2), or purified HuD-GST (lane 3) UV cross-linked to $\left[{ }^{32} \mathrm{P}\right]-$ labeled tau RNA fragment I. NIS is the complex formed with normal serum (lane 4 ). Lanes 5 and 6 show unprecipitated PC12 extract and GST-HuD protein analyzed immediately after cross-linking.

Figure 9, formation of the tau-H-HuD complex was detectable at $3 \mathrm{~nm}$ and had a midpoint at $\sim 100 \mathrm{~nm}$. Complex formation with tau-F RNA was not detectable under these conditions. A plot of the log of complexed/free RNA versus the log of HuD concentration yields a straight line. At 50\% complex formation the intercept on the $x$-axis corresponds to $131 \mathrm{~nm}$ (Fig. 9). Thus, the binding of $\mathrm{HuD}$ to tau mRNA is a simple molecular reaction with an apparent $\mathrm{Kd}$ of $131 \mathrm{~nm}$. Similar kinetic data were recently obtained for GAP-43 mRNA (Chung et al., 1997).

\section{HuD binds to a conserved U-rich segment in tau mRNA}

To localize the HuD-binding region within the $\mathrm{H}$ segment of tau mRNA, we used the RNase T1 selection analysis that we have

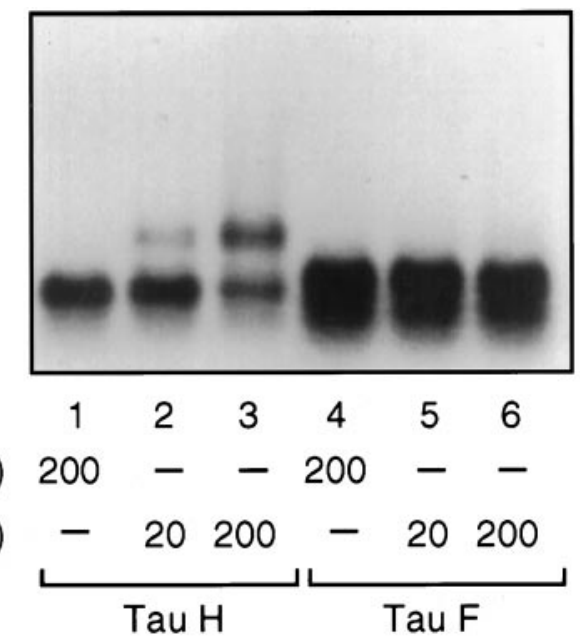

Figure 8. Purified HuD binds to tau mRNA. The indicated $\left[{ }^{32} \mathrm{P}\right]$-labeled RNAs were incubated with the indicated concentrations of GST or HuD. After incubation, the reaction mixture was resolved by gel electrophoresis in $0.8 \%$ agarose gel.

used previously to analyze other mRNAs. In this technique, the HuD-RNA complex is formed and is then digested with RNase T1. The specific RNA fragments bound to $\mathrm{HuD}$ are isolated by allowing the complex to be absorbed by nitrocellulose filter (under the conditions used, uncomplexed RNA passes through). The RNA fragments bound to HuD are then eluted from the nitrocellulose with phenol-chloroform (Chung et al., 1996). The pattern of digestion of tau-H RNA with RNase T1 is shown in Figure 10 (lane 3). The tau-H RNA contains two large RNase T1 oligonucleotides that are not resolved, because small RNAs migrate according to size and base composition. The two oligonucleotides can be distinguished by analysis of tau fragments I and $\mathrm{J}$, which are subfragments of $\mathrm{H}$ (Figs. 6, 10). $\mathrm{HuD}$ was found to bind to the U-rich region present in fragments $\mathrm{H}$ and I (Fig. 10, lanes 2, 5) but not $\mathrm{J}$ (lane 8). Thus we can conclude that HuD binds within the U-rich segment located within fragment I (Fig. 6, boxed area). The selected species was resistant to further digestion with RNase T1. The precise assignation of the binding site cannot be made because of the close ladder observed in the lanes demonstrating the presence of the complex formed between $\mathrm{HuD}$ and RNA transcript. The reasons for the multiple bands are technical and stem from the length of the U-rich region, which causes stuttering of the RNA polymerase during synthesis of the transcript. This binding region is similar in sequence to those observed in other mRNAs (Chung et al., 1997; Jain et al., 1997; Joseph et al., 1998). Our assignment of the binding region was further validated by RNase T1 selection experiments using RNA transcribed from a Gdel fragment (lanes 13-15). Deletion of the 21 nucleotides of the U-rich region from fragment $\mathrm{G}$ (lanes 10-12), which is also included in fragment $\mathrm{H}$ (Behar et al., 1995), abolished the binding of purified HuD protein (lane 14). Similar results were observed when UV cross-linking assay was performed using RNA transcribed from the same fragments incubated with purified GST-HuD protein or protein extracts prepared from PC12 cells (Fig. 10, $A$ and $B$, respectively).

\section{DISCUSSION}

The ELAV-like RNA-binding proteins are a conserved protein family involved in growth, differentiation, and post-transcriptional 
A
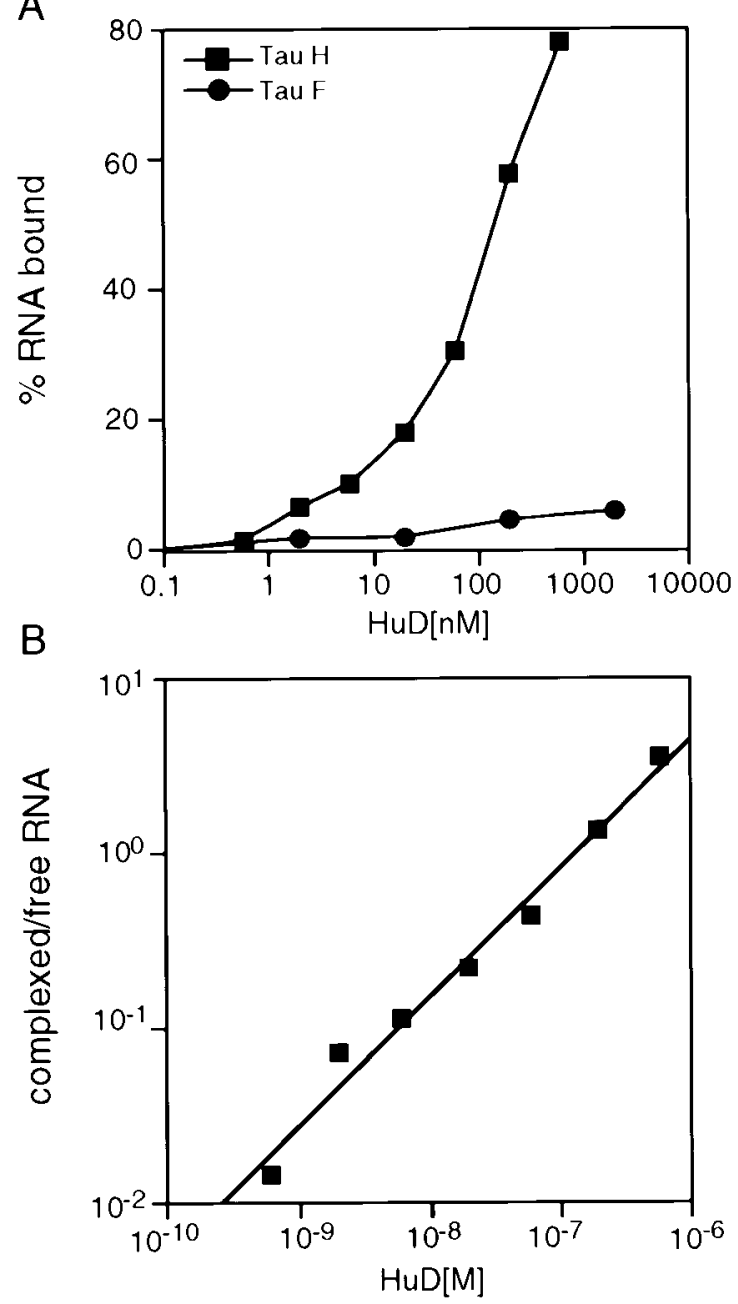

Figure 9. Affinity of $\mathrm{HuD}$ for tau mRNA. The affinity of purified HuD-GST for tau mRNA was determined by nitrocellulose filter binding assay, as described in Materials and Methods. $A$, Plot of percentage of bound RNA versus $\log$ of $\mathrm{HuD}$ concentration. $B$, Plot of $\log$ of ratio between complexed/free RNA versus log of HuD concentration.

gene expression (Antic and Keene, 1997; Good, 1997). Among these proteins $\mathrm{HuD}, \mathrm{HuC}$, and Hel-N1 are exclusively neuronal and are expressed in postmitotic neurons and in neuroendocrine tumors (Dalmau et al., 1992; King et al., 1994; Marusich et al., 1994). These proteins bind to U-rich elements found in a wide variety of mRNAs, and it was therefore suggested that such binding might target them for rapid degradation (Chen and Shyu, 1995). Recent findings suggest that ELAV-like proteins help to stabilize a specific subset of mRNAs, which may be involved in the mechanism leading to neuronal differentiation (Antic and Keene, 1997; Jain et al., 1997; Myer et al., 1997; Fan and Steitz, 1998; Levy et al., 1998; Peng et al., 1998).

In a previous study we identified neuronal RNA-binding proteins that specifically recognize the $3^{\prime}$-UTR region of tau mRNA (Behar et al., 1995) present in extracts prepared from rat brains and PC12 cells. In the present study we characterized these RNA-binding proteins as the ELAV-like proteins (Fig. 7) (Chung et al., 1996). This discovery might represent an important link between proteins that regulate neuronal differentiation at the post-transcriptional level and a target mRNA that encodes a neuron-specific protein required for differentiation. Furthermore, we demonstrated the interaction between the endogenous ELAV-like protein and tau mRNA in vivo (Figs. 3, 4). Inhibition of $\mathrm{HuD}$ expression in $\mathrm{PC} 12$ cells abolished their response to NGF-induced differentiation, with concomitant downregulation of tau mRNA (Figs. 1, 2). GAP-43 is another neuronal target mRNA that binds to and is stabilized by the ELAV-like protein (Chung et al., 1997).

The PC12 cell line serves as a useful model to study many steps of neuronal differentiation (Greene and Tischler, 1976). However, NGF induction in PC12 cells results in neurite extension and not in the elaboration of defined dendrites and axons. It therefore remains to be seen whether tau expression during the early stages of brain development is regulated by the ELAV-like proteins. The kinetics of ELAV-like protein induction during development are consistent with such a role, because these proteins are expressed immediately after the withdrawal from the mitotic cycle (Marusich et al., 1994; Barami et al., 1995), which happens before the induction of tau or GAP-43. Recent data indeed demonstrate that $\mathrm{HuD}$ protein binds to a conserved U-rich region within the $3^{\prime}$-UTR of p21 waf1 mRNA, a protein that is involved in arresting the cell cycle in PC12 cells, a requirement for initiating neuronal differentiation (Yan and Ziff, 1995, 1997). Taken together, these findings might suggest that the ELAV-like proteins may regulate the stability of a subclass of mRNAs in a time-specific manner, thereby regulating neuronal differentiation.

From the present study and recent work on Hel-N1 and HuR (Changnovich et al., 1996; Jain et al., 1997; Levy et al., 1998; Peng et al., 1998; Antic et al., 1999), it is clear that the ELAV-like proteins act by increasing the amounts of their target mRNAs and/or translatability, which may be linked in some cases. Our results demonstrate specific binding both in vitro and in vivo to a U-rich region located in tau $3^{\prime}$-UTR (Figs. 8-10). The current concept is that the ELAV-like proteins bind to the U-rich element and thus prevent the selective turnover of that mRNA. Unlike other mRNA targets, tau mRNA is a relatively stable molecule (Sadot et al., 1995). In a recent study, we showed that fragment H (Fig. 6) of the tau 3'-UTR, which contains the U-rich region, is responsible for tau mRNA stability and confers stability on heterologous c-fos after transfection into neuronal cells (Aronov and Ginzburg, 1999). It thus seems that in addition to inhibition of selective decay, the ELAV-like proteins may serve as linkers between a target mRNA and MTs, thus anchoring the message and protecting it from degradation. We have shown previously that localization of tau mRNA involves an association with the functional MT system. This was evident both in neuronal cells (Litman et al., 1994) and in microinjected Xenopus oocytes, where additional proteins are involved (Litman et al., 1996). In the present work we showed that ELAV-like proteins fractionate with MT (Fig. 4). In addition, confocal microscopy showed colocalization of the ELAV-like proteins on MTs and extension into the neurites of PC12 cells (Fig. 5). We therefore suggest that ELAV-like proteins may be a component of the RNA-protein particles that were recently described in the RNA localization pathway (Ainger et al., 1993; Wilhelm and Vale, 1993). These particles are localized near MTs and contain both the targeted mRNA and several additional protein factors, including protein synthetic machinery and possibly proteins involved in mRNA stabilization and anchorage (Hamill et al., 1994; Barbarese et al., 1995). In agreement with this notion is the finding that Hel-N1 is present in granular RNA protein structures that contain mRNA 

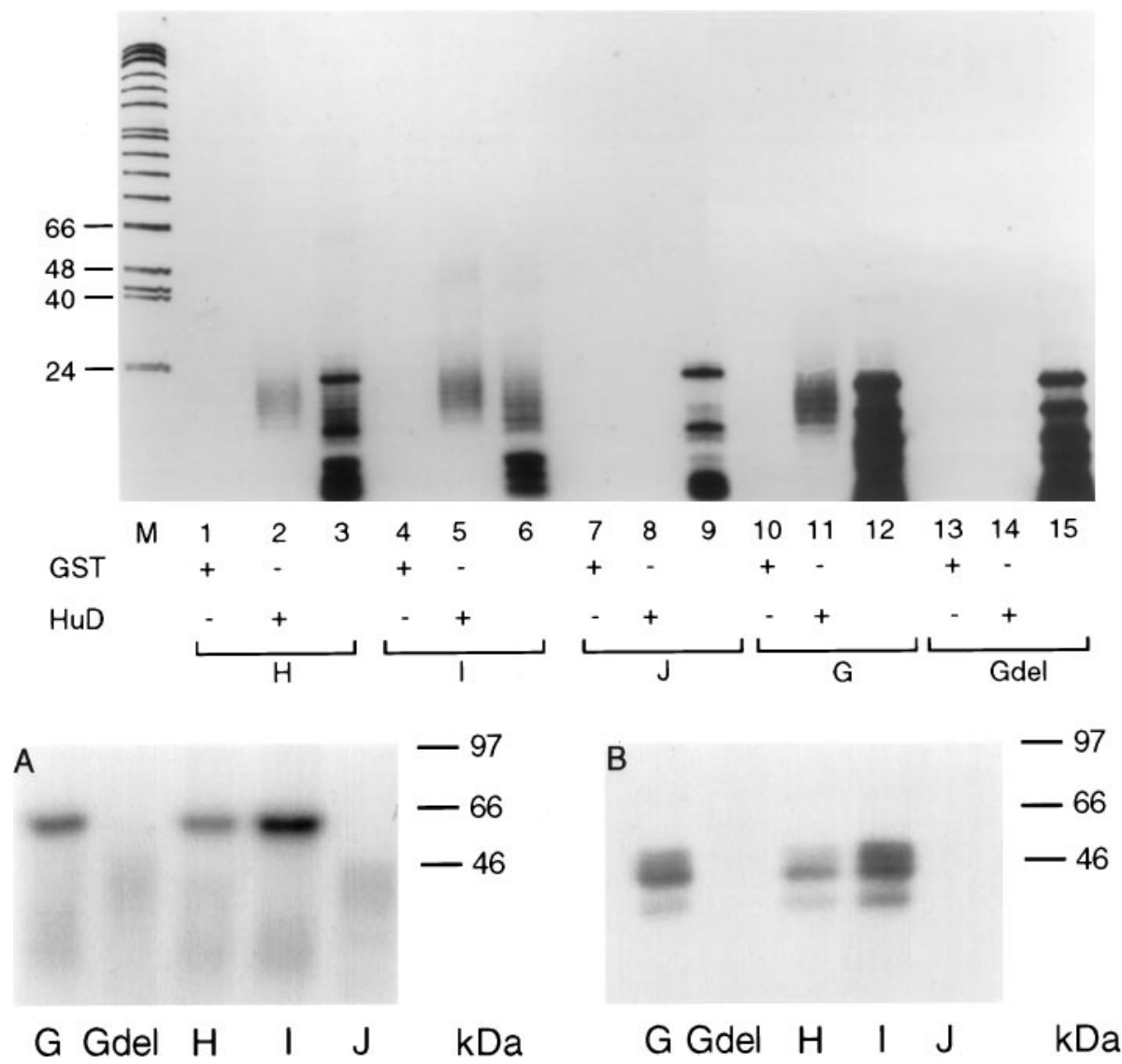

Figure 10. RNase T1 selection analysis of the $\mathrm{HuD}$ binding region in the tau- $\mathrm{H}$ fragment. RNase T1 selection assay was performed as described previously (Chung et al., 1996) with GST (lanes 1, 4, 7, 10,13) or HuD (lanes 2, 5, 8, 11, 14 ), incubated with [ $\left.{ }^{32} \mathrm{P}\right]-$ labeled $H, I, J, G$, and Gdel RNAs, respectively. The reaction mixture was treated with RNase T1 and filtered through nitrocellulose to select for the RNA/protein complexes. After washing, the fragments were eluted and resolved on a $12 \%$ denaturing polyacrylamide gel. Lanes 3, 6, 9, 12, and 15 are the total unselected RNase $\mathrm{T} 1$ digests of the indicated fragments. $A, \mathrm{UV}$ cross-linking assay with purified GST-HUD. $B$, UV cross-linking assay with $\mathrm{PC} 12$ protein extracts. and ribosomes (Gao and Keene, 1996; Antic and Keene, 1998). Indeed a pleasing aspect of this model is that it may explain the diversity of ELAV-like proteins in neuronal cells. It is possible that the three neuronal members, $\mathrm{HuD}, \mathrm{HuC}$, and $\mathrm{Hel}-\mathrm{N} 1$, are involved in different localization pathways. It is important to note, however, that there must be an additional level of specificity. For example, HuD binds in vitro to a large number of mRNAs that contain the U-rich element (Chung et al., 1996, 1997; Ma et al., 1997). Obviously, not all of these mRNAs are localized in the same cellular microdomains. Moreover, the ELAV-like proteins do not appear to differ significantly in the way they bind to particular RNA targets. It was shown recently that only a subset of mRNAs is associated with MTs as ELAV mRNP particles that associate with the translational apparatus (Antic and Keene, 1998). In vivo, therefore, it is likely that other conserved flanking sequences and trans-acting specific factors are involved.

Neuronal polarity, which is required for neuronal plasticity, depends on interaction between neuron-specific mRNAs and a family of proteins regulating their expression. Subcellular RNA localization has been described in germ cells, as well as in somatic cells such as fibroblasts, muscle cells, and neurons (Wilhelm and Vale, 1993; St. Johnston, 1995), as a mechanism responsible for creating the polarity that involves synergistic controls of translation, stabilization, and association with the cytoskeleton. Such controls are mediated primarily through the $3^{\prime}$-UTRs of the mRNAs. Regulation of the stability of these mRNAs is crucial during movement and establishment of the cell polarity as well as subsequent controlling of their levels at the different compartments (Gao, 1998).

Understanding of the interaction between tau mRNA and ELAV-like proteins may help to explain the control of tau mRNA stabilization, which is important for neuronal differentiation and its subcellular localization process. Although the molecular mechanism by which the ELAV-like proteins control the half-life of specific messages remains to be determined, our results show that these proteins bind to specific cis-sequences in the $3^{\prime}$-UTR and thus facilitate their binding to the MTs. This mechanism may shed light on the physiological function of the ELAV-like protein family in differentiation and maintenance of the neuronal system.

\section{REFERENCES}

Aronov S, Marx R, Ginzburg I (1999) Identification of 3' UTR sequences implicated in tau mRNA stabilization. $\mathbf{J}$ Mol Neurosci, in press.

Abe R, Uyeno Y, Yamamoto K, Sakamoto H (1994) Tissue-specific expression of the gene encoding a mouse RNA binding protein homologous to human HuD antigen. DNA Res 1:175-180.

Ainger K, Avossa D, Morgan F, Hill SJ, Barry C, Barbarese E, Carson JH (1993) Transport and localization of exogenous myelin basic protein mRNA microinjected into oligodendrocytes. J Cell Biol 123:431-441.

Antic D, Keene JD (1997) ELAV RNA-binding proteins involved in growth, differentiation and post-transcriptional gene expression. Am J Hum Genet 61:273-278.

Antic D, Keene JD (1998) Messenger ribonucleoprotein complexes containing human ELAV proteins: interactions with cytoskeleton and translational apparatus. J Cell Sci 111:183-197.

Antic D, Lu N, Keene JD (1999) ELAV tumor antigen, Hel-N1, increases translation of neurofilament M mRNA and induces formation of neurites in human teratocarcinoma cells. Genes Dev 13:449-461.

Barami K, Iversen K, Furneaux H, Goldman S (1995) Hu protein as an early marker of neuronal phenotypic differentiation by subependymal zone cells of adult songbird forebrain. J Neurol 28:82-101.

Barbarese E, Koppel DE, Deutscher MP, Smith CL, Ainger K, Morgan F, Carson JH (1995) Protein translation components are colocalized in granules in oligodendrocytes. J Cell Sci 108:2781-2790.

Behar L, Marx R, Sadot E, Barg J, Ginzburg I (1995) cis-Acting signals 
and trans-acting proteins are involved in tau mRNA targeting into neurites of differentiating neuronal cells. Int $\mathrm{J}$ Dev Neurosci 13:113-127.

Binder LI, Frankfurter A, Rebhun LI (1985) The distribution of tau polypeptides in the mammalian central nervous system. J Cell Biol 101:1371-1378.

Black MM, Kurdyla T (1983) Microtubule-associated proteins of neurons. J Cell Biol 97:1020-1028.

Caceres A, Kosik KS (1990) Inhibition of neurite polarity by tau antisense oligonucleotides in primary cerebellar neurons. Nature 343:461-463.

Campos AR, Grossman D, White K (1985) Mutant alleles at the locus elav in Drosophila melanogaster lead to nervous system defects. A developmental-genetic analysis. J Neurogenet 2:197-218.

Carey J, Cameron V, de Haseth PL, Uhlenbeck OC (1983) Sequencespecific interaction of R17 coat protein with its ribonucleic acid binding site. Biochemistry 22:2601-2610.

Changnovich D, Fayos BE, Cohn SL (1996) Differential activity of Elavlike RNA binding proteins in human neuroblastoma. J Biol Cell 271:33587-33591.

Chen C-YA, Shyu A-B (1995) AU-rich elements: characterization and importance in mRNA degradation. Trends Biol Sci 20:465-470.

Chung S, Jiang L, Cheng S, Furneaux H (1996) Purification and properties of HuD, a neuronal RNA-binding protein. J Biol Chem 271:11518-11524.

Chung S, Perrone-Bizzozero N, Kohn DT, Furneaux H (1997) The Elav-like proteins bind to a conserved regulatory element in the $3^{\prime}$ UTR of GAP-43 mRNA. J Biol Chem 272:6593-6598.

Dalmau J, Furneaux HM, Cordon-Cardo C, Posner JB (1992) The expression of the $\mathrm{Hu}$ (paraneoplastic encephalomyelitis/sensory neuropathy) antigen in human normal and tumor tissues. Am J Pathol 141:881-886.

Dobashi Y, Mitsuhiko S, Wakata Y, Kameya T (1998) Expression of HuD protein is essential for initial phase of neuronal differentiation in PC12 cells. Biochem Biophys Res Commun 244:226-229.

Fan XC, Steitz JA (1998) Overexpression of HuR, a nuclear-cytoplasmic shuttling protein, increases the in vivo stability of ARE-containing mRNAs. EMBO J 17:3448-3460.

Gao FB (1998) Messenger RNAs in dendrites: localization, stability, and implications for neuronal function. BioEssays 20:70-78.

Gao FB, Carson C, Levine T, Keene J (1994) Selection of a subset of mRNAs from libraries using Hel-N1. Proc Natl Acad Sci USA 91:11207-11211.

Gao FB, Keene D (1996) Hel-N1/Hel-N2 proteins are bound to poly (A) + mRNA in granular RNP structures and are implicated in neuronal differentiation. J Cell Sci 109:579-589.

Good PJ (1995) A conserved family of elav-like genes in vertebrates. Proc Natl Acad Sci USA 92:4557-4561.

Good PJ (1997) The role of elav-like genes, a conserved family encoding RNA-binding proteins, in growth and development. Semin Cell Dev Biol 8:557-584.

Greene LA, Tischler A (1976) Establishment of a noradrenergic clonal line of rat adrenal pheochromocytoma cells which respond to nerve growth factor. Proc Natl Acad Sci USA 73:2424-2428.

Hamill D, Davis J, Drawbridge J, Suprenant KA (1994) Polyribosome targeting to microtubule: enrichment of specific mRNAs in a reconstituted microtubule preparation from sea urchin embryos. J Cell Biol 127:973-984.

Hanemaaijer R, Ginzburg I (1991) Involvement of mature tau isoforms in the stabilization of neurites in PC12 cells. J Neurosci Res 30:163-171.

Homyk JT, Isono K, Pak WL (1985) Development and physiological analysis of a conditional mutation affecting photoreceptor and optic lobe development in Drosophila melanogaster. J Neurogenet 2:309-324.

Jain RG, Andrews LG, McGowan KM, Pekala PH, Keene JD (1997) Ectopic expression of Hel-N1, an RNA-binding protein, increases glucose transporter (GLUT1) expression in 3T3-L1 adipocytes. Mol Cell Biol 17:954-962.

Jimenez F, Campos-Ortega JA (1987) Genes in subdivision 1B of the Drosophila melanogaster X-chromosome and their influence on neural development. J Neurogenet 4:179-200.

Joseph B, Orlian M, Furneaux H (1998) p21waf1 mRNA contains a conserved element in its $3^{\prime}$-untranslated region that is bound by the Elav like mRNA-stabilizing proteins. J Biol Chem 273:20511-20516.
Kenan DJ, Query CC, Keene JD (1991) RNA recognition: towards identifying determinants of specificity. Trends Biochem Sci 16:214-220.

King PH, Levine TD, Fremeau RT, Keene JD (1994) Mammalian homologues of Drosophila ELAV localized to a neuronal subset can bind in vitro to the $3^{\prime}$ UTR of mRNA encoding the Id transcriptional repressor. J Neurosci 14:1943-1952.

Koushika SP, Lisbin MJ, White K (1996) ELAV, a Drosophila neuronspecific protein, mediates the generation of an alternatively spliced neural protein isoform. Curr Biol 6:1634-1641.

Levy NS, Chung S, Furneaux H, Levy AP (1998) Hypoxic stabilization of VEGF mRNA by the RNA-binding protein HuR. J Biol Chem 273:6417-6423.

Litman P, Barg J, Ginzburg I (1994) Microtubules are involved in the localization of tau mRNA in primary neuronal cell culture. Neuron 13:1463-1474.

Litman P, Behar L, Elisha Z, Yisraeli JK, Ginzburg I (1996) Exogenous tau RNA is localized in oocytes: possible evidence for evolutionary conservation of localization mechanisms. Dev Biol 176:86-94.

Ma W, Furneaux H (1997) Localization of the human HuR gene to chromosome 19p13.2. Hum Genet 99:32-33.

Ma WJ, Jiang L, Cheng JS, Furneaux HM (1997) The Elav-like RNA binding proteins bind to AU-rich elements and to the poly(A) of mRNA. Nucleic Acids Res 25:3564-3569.

Marusich MF, Furneaux HM, Henion PD, Weston JA (1994) Hu neuronal proteins are expressed in proliferating neurogenic cells. J Neurobiol 25:143-155.

Meakin SO, Suter U, Drinkwater CC, Welcher AA, Shooter EM (1992) The rat trk protooncogene product exhibits properties characteristic of the slow nerve growth factor receptor. Proc Natl Acad Sci USA 89:2374-2378.

Myer VE, Fan XC, Steitz JA (1997) Identification of HuR as a protein implicated in AUUUA-mediated mRNA decay. EMBO J 16:2130-2139.

Nudel U, Zakut R, Shani M, Neuman S, Levy Z, Yaffe D (1983) The nucleotide sequence of the rat cytoplasmic beta-actin gene. Nucleic Acids Res 11:1759-1771.

Okano HJ, Darnell RB (1997) A hierarchy of Hu RNA binding proteins in developing and adult neurons. J Neurosci 17:3024-3037.

Peng SS, Chen CY, Xu N, Shyu AB (1998) RNA stabilization by the AU-rich element binding protein, HuR, an ELAV protein. EMBO J 17:3461-3470.

Perron M, Theodore L, Wegnez M (1995) Isolation and embryonic expression of Xel-1, a nervous system-specific Xenopus gene related to the elav gene family. Mech Dev 51:235-249.

Premont RT, Chen J, Ma HW, Ponnapalli M, Iyengar R (1992) Two members of a widely expressed subfamily of hormone-stimulated adenylyl cyclases. Proc Natl Acad Sci USA 89:9809-9813.

Radeke MJ, Misko TP, Hsu C, Herzenberg LA, Shooter EM (1987) Gene transfer and molecular cloning of the rat nerve growth factor receptor. Nature 325:593-597.

Robinow S, Campos AR, Yao KM, White K (1988) The elav gene product of Drosophila, required in neurons, has three RNP consensus motifs. Science 242:1570-1572.

Robinow S, White AK (1991) Characterization and spatial distribution of the Elav protein during Drosophila melanogaster development. J Neurobiol 22:443-461.

Sadot E, Marx R, Barg J, Behar L, Ginzburg I (1994) Complete sequence of 3 '-untranslated region of tau from rat central nervous system: implications for mRNA heterogeneity. J Mol Biol 241:325-331.

Sadot E, Barg J, Rasouly D, Lazarovici P, Ginzburg I (1995) Short- and long-term mechanisms of tau regulation in PC12 cells. J Cell Sci 108:2857-2864

Sakai K, Gofuko M, Kitagawa Y, Ogasawara T, Hirose G, Yamazaki, Koh C, Yanagisawa N, Steinman L (1994) A hippocampal protein associated with paraneoplastic neurologic syndrome and small cell lung carcinoma. Biochem Biophys Res Commun 199:1200-1208.

Shaw G, Kamen R (1986) A conserved AU sequence from the $3^{\prime}$ untranslated region of GM-CSF mRNA mediates selective mRNA degradation. Cell 46:659-667.

Shelanski ML, Gaskin F, Cantor CR (1973) Microtubule assembly in the absence of added nucleotides. Proc Natl Acad Sci USA 70:765-768.

St. Johnston D (1995) The intracellular localization of messenger RNAs. Cell 81:161-170.

Steller U, Kohls S, Muller B, Soler R, Muller R, Schlender J, Blohm DH (1996) The RNA binding protein HuD: rat cDNA and analysis of the 
alternative spliced mRNA in neuronal differentiating cell lines P19 and PC12. Mol Brain Res 35:285-296.

Szabo A, Dalmau J, Manley G, Rosenfeld M, Wong E, Henson J, Posner JB, Furneaux HM (1991) HuD, a paraneoplastic encephalomyelitis antigen, contains RNA binding domains and is homologous to Elav and Sex-lethal. Cell 67:325-333.

Tso JY, Sun XH, Reece KS, Wu R (1985) Isolation and characterization of rat and human glyceraldehyde-3-phosphate dehydrogenase cDNAs: genomic complexity. Nucleic Acids Res 13:2485-2502.

Wakamatsu Y, Weston JA (1997) Sequential expression and role of $\mathrm{Hu}$ RNA-binding proteins during neurogenesis. Development 124: $3449-3460$
Wilhelm JE, Vale RD (1993) RNA on the move: the mRNA localization pathway. J Cell Biol 123:269-274.

Yan GZ, Ziff EB (1995) NGF regulates the PC12 cell cycle machinery through specific inhibition of the Cdk kinases and induction of cyclin D1. J Neurosci 15:6200-6212.

Yan GZ, Ziff EB (1997) Nerve growth factor induces transcription of the p21 WAF1/CIP1 and cyclin D1 genes in PC12 cells by activating the Sp1 transcription factor. J Neurosci 17:6120-6132.

Yao KM, Samson ML, Reeves R, White K (1993) Gene elav of Drosophila melanogaster: a prototype for neuronal-specific RNA binding protein gene family that is conserved in flies and humans. J Neurobiol 24:723-739. 